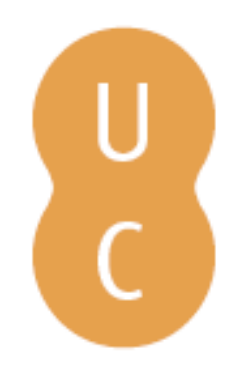

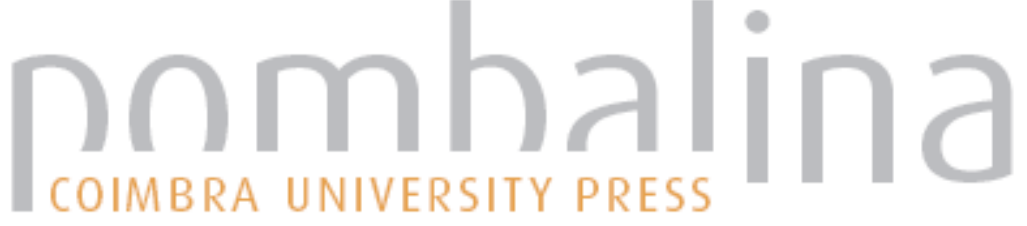

\section{Linguagem, barbarismo e civilização: Hélia Correia, Desmesura}

Autor(es): $\quad$ Silva, Maria de Fátima

Publicado por: Imprensa da Universidade de Coimbra

URL

persistente:

URI:http://hdl.handle.net/10316.2/32323

DOI:

DOI:http://dx.doi.org/10.14195/978-989-26-0391-9_11

Accessed : $\quad$ 26-Apr-2023 13:19:34

A navegação consulta e descarregamento dos títulos inseridos nas Bibliotecas Digitais UC Digitalis, UC Pombalina e UC Impactum, pressupõem a aceitação plena e sem reservas dos Termos e Condições de Uso destas Bibliotecas Digitais, disponíveis em https://digitalis.uc.pt/pt-pt/termos.

Conforme exposto nos referidos Termos e Condições de Uso, o descarregamento de títulos de acesso restrito requer uma licença válida de autorização devendo o utilizador aceder ao(s) documento(s) a partir de um endereço de IP da instituição detentora da supramencionada licença.

Ao utilizador é apenas permitido o descarregamento para uso pessoal, pelo que o emprego do(s) título(s) descarregado(s) para outro fim, designadamente comercial, carece de autorização do respetivo autor ou editor da obra.

Na medida em que todas as obras da UC Digitalis se encontram protegidas pelo Código do Direito de Autor e Direitos Conexos e demais legislação aplicável, toda a cópia, parcial ou total, deste documento, nos casos em que é legalmente admitida, deverá conter ou fazer-se acompanhar por este aviso.

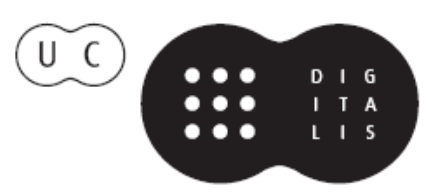


Maria de Fátima Sousa e Silva

Coordenação

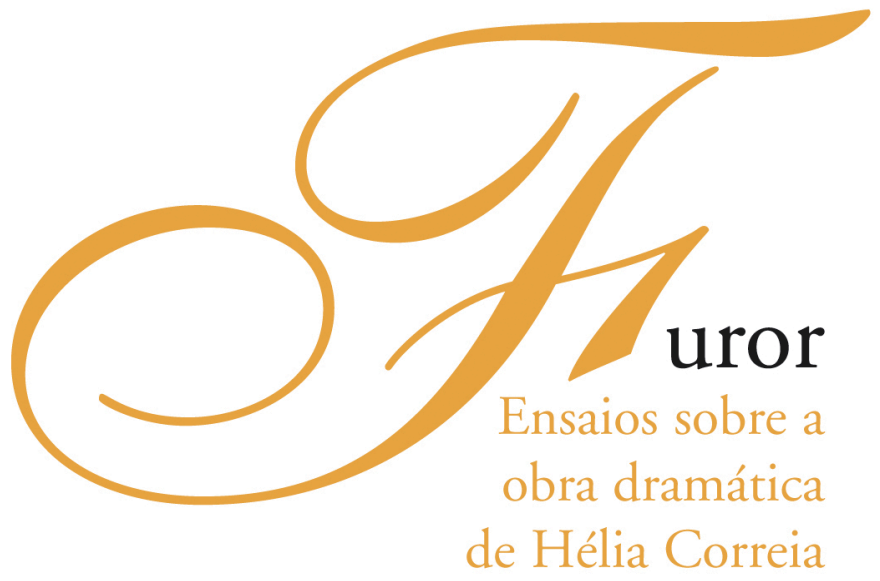

- COIMBra 2006 
COORDENAÇÃO EDITORIAL

Imprensa da Universidade de Coimbra

URL: http//www.imp.uc.pt

\author{
CONCEPÇÃO GRÁFICA \\ António Barros \\ PAGINAÇÃO \\ Inova \\ EXECUÇÃO GRÁFICA \\ Inova - Artes Gráficas \\ Porto
}

ISBN

972-8704-94-1

DEPÓSITO LEGAL

247166/06

C OUTUBRO, 2006, IMPRENSA DA UNIVERSIDADE DE COIMBRA

OBRA PUBLICADA COM O APOIO DE:

Centro de Estudos Clássicos e Humanísticos

FCT Fundação para a Ciência e a Tecnologia

MINISTÉRIO DA CIÊNCIA, TECNOLOGIA E ENSINO SUPERIOR Portugal 
Maria de Fátima Sousa e Silva

Coordenação

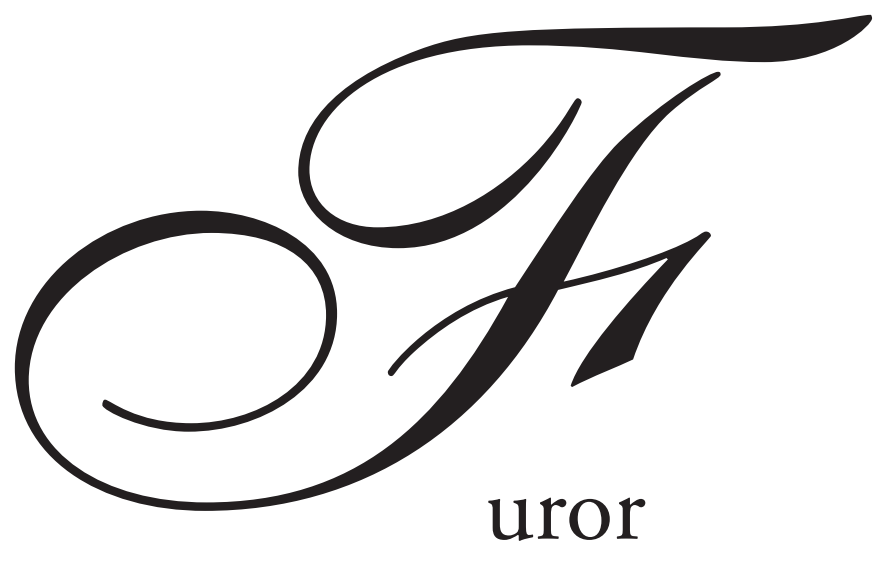

\author{
Ensaios sobre a \\ obra dramática \\ de Hélia Correia
}



Maria de Fátima Silva

Universidade de Coimbra

\title{
LINGUAGEM, BARBARISMO E CIVILIZAÇÃO HÉLIA CORREIA, DESMESURA
}

\author{
"É a palavra um senhor poderoso que, com o seu corpo minúsculo \\ e invisível, \\ leva a cabo obras dignas de deuses. \\ Sabe como fazer calar o medo, arredar a dor, \\ provocar alegria, despertar compaixãon.
}

Górgias, Elogio de Helena 8

Dentro da produção dramática que Hélia Correia tem dedicado a temas clássicos, privilegiando grandes figuras femininas, após Perdição. Exercício sobre Antígona ${ }^{1}$ e Rancor. Exercício sobre Helena ${ }^{2}$, chegou a vez de Desmesura. Exercício com Medeia ${ }^{3}$.

Seguindo, nas suas grandes linhas, o desenvolvimento euripidiano do mito, Hélia acentua alguns dos que são os traços característicos do episódio coríntio da história da princesa da Cólquida: o conflito que a heroína tem de travar com o amante, devedor do seu amor e conivência na aventura do velo de ouro, que agora a repudia em nome do interesse numa aliança mais promissora; o desajuste, particularmente sensível, entre a sua identidade bárbara e o mundo grego, onde permanece vítima de todas as penas do exílio; para além daquele temor

\footnotetext{
${ }^{1}$ Lisboa, Publicações D. Quixote, 1991.

2 Lisboa, Relógio d’Água, 2000.

${ }^{3}$ Texto ainda inédito, que me foi dado a conhecer pela generosidade da Autora. As citações são feitas sobre o texto policopiado.
} 
que em todos quantos a cercam desperta a sua natureza, determinada, violenta, numa palavra só, desmesurada, que culmina na atrocidade de um filicídio.

Subjacente à recriação do episódio, Hélia valoriza, no entanto, como elemento catalizador das diferentes cambiantes da história, o efeito, poder e precisão da palavra. Evoca de certa forma, com esta preferência, a relevância do elemento retórico na versão euripidiana que lhe serve de modelo. Também o trágico conferiu aos seus heróis a capacidade de reflectir e de se expressar de acordo com os cânones retóricos em vigor. Mas embora, nos dois agônes em que se confrontam, Jasão e Medeia se revelem hábeis utilizadores dos recursos oratórios, não logram obter o sucesso prometido pelo uso hábil da palavra, o de persuadir o interlocutor. Quem sabe se afinal, como Hélia nos levará a concluir, porque lhes faltem os termos exactos para esgrimir perante os sentimentos que os dominam.

Desde logo é sugestiva, em Desmesura, a escolha criteriosa dos nomes, sobretudo os que rotulam as figuras não convencionais que passam a integrar esta nova versão; são eles, na sua convenção de inspiração cromática, uma réplica particularmente feliz da velha tradição dos nomes falantes, que o teatro antigo, principalmente a comédia, explorou à saciedade ${ }^{4}$. Depois as diversas tensões, que opõem, pelo estatuto social, senhores e escravas, ou gregos e bárbaras, ou homens e mulheres, têm na linguagem mais do que o veículo natural da sua expressão, a ferramenta que lhes garante uma construção ajustada, firme e estável. Como se Hélia, em cada momento da sua criação, tivesse tomado, como lema primeiro, a famosa orthoépeia, tão proclamada pela intelectualidade sofística que rodeou Eurípides e onde o poeta de Salamina foi beber muito do que constituiu o seu gosto estético 5 .

Dentro de uma tendência que se verifica já em Perdição e Rancor, a autora reforça, em torno da heroína, um círculo feminino, que constitui um primeiro

\footnotetext{
${ }^{4}$ Cf., e. g., G. E. Duckworth, The nature of Roman comedy, Princeton, reimpr. 1971, pp. 345-350.
} 
centro de confrontos e tensões. Também este enquadramento estava previsto na Medeia de Eurípides, representado, por oposição, pela figura solidária e próxima de uma Ama, conhecedora profunda da ameaça terrível que a ira da sua senhora representava ${ }^{6}$, em contraste com a distante Glauce, a princesa de Corinto, rival nos interesses de Jasão, mas vulnerável na sua ignorância sobre a verdadeira dimensão da cólera que o seu sonho de amor despoletava. Hélia altera a personalidade da noiva de Jasão, que continua vítima de uma fantasia, mas consciente agora de um ardil de atracção, que a fúria de Medeia irá arrasar com o poder destruidor dos seus filtros de feiticeira. Se algo se acentua como novidade é a sedução poderosa e consciente que, desta vez, a princesa detém. Favorece-a a própria natureza, que a dotou de «uns belos olhos verdes» (p. 29) que já o nome de Glauce patenteia, e dos fulgores atraentes de uma cabeleira ruiva. Mas não é inócua ou involuntária a sedução que a filha de Creonte possui, como mera generosidade de physis. Esta outra Glauce está consciente do poder das armas de que dispõe e, por isso, não pôde evitar um sorriso de triunfo no momento em que uma escrava, emissária de Medeia, lhe depositava nas mãos um presente tentador (p. 29): «Fitou em mim seus belos olhos verdes (...) e não vi neles pureza nem bondade: vi a dona de um ardil que triunfou». E em resposta à pergunta angustiada de Medeia sobre a eficácia imediata da

\footnotetext{
5 Este é um conceito especificamente associado ao nome de Protágoras, e que teve em Pródico, com o seu lema da onomáton orthótes, um continuador (cf. Platão, Eutidemo 277e, Fedro 267c, Protágoras 339a, Crátilo 384b, 391 a-c; Aristóteles, Retórica 1407b, Poética 1456b 15-18); ao conceito, sobretudo formal, da orthoépeia, Pródico substituiu a prática da análise discriminatória dos diversos termos, cada um em oposição com os outros (diaíresis), como orientação dos seus discípulos no uso preciso de cada vocábulo. Sobre a questão, vide R. Pfeiffer, History of Classical Scholarship from the beginnings to the end of the Hellenistic Age, I, Oxford, 1968, pp. 32-56; P. B. R. Forbes, 'Greek pioneers in Philology and Grammar', Classical Review 47, 1933, pp. 105-112; Ch. Segal, 'Protagoras orthoepeia in Aristophanes' battle of the prologues', Rheinisches Museum 113, 1970, pp. 158-162 Com A. Plebe, 'Origini e problemi dell'estetica antica', in Momenti e problemi di storia dell' estetica, a cura di M. Fubini, Milano, 1979, p. 18, queremos recordar: "Oportunidade psicológica, coerência da linguagem, arte de persuadir são portanto os três eixos em que assenta a estética dos primeiros sofistas, que com legítimo direito se poderiam reclamar pioneiros da estética na Antiguidade».

${ }^{6}$ Sobre a figura da Ama no teatro de Eurípides, cf. M. F. Silva, Ensaios sobre Eurípides, Lisboa, 2005, pp. $178-181$.
} 
vingança que desencadeou (p. 29): «Há-de querer exibir o teu penhor, a bela prova de que te venceu e te neutralizou o coração».

A mesma competição, patente e agressiva, se estende também ao círculo próximo de Medeia. À Ama solidária da versão helénica, Hélia substitui uma escrava, que é marcadamente grega e desde logo uma potencial inimiga da bárbara, mas também uma vítima sofrida da vida que a não poupou, alimentando, no âmago de si mesma, alguma revolta contra a senhora, estranha e estrangeira, que se viu compelida a servir. A seu lado, serva também, vive uma filha, penhor amargo daquela violação desapaixonada, com que os senhores se servem do corpo das mulheres que lhes povoam a casa, ao seu serviço ${ }^{7}$. Para as duas encontrou a Autora os sugestivos nomes de Melana «a negra» e Éritra «a fulva».

Acumulam-se os dados que revestem estes nomes de um conteúdo. Na rubrica de cena que abre a Parte I (p. 4), para o nome de Melana é dada a justificação mais óbvia, a de que se aplica a «uma mulher que ainda não fez quarenta anos, morena». A moldura em volta de Melana é harmoniosa com a personagem: fechada no interior de uma cozinha, "olha para a porta, como quem espera»; imobilidade, abulia, desencanto são os traços a negro do retrato. Mas, em breve, a atitude misteriosa e sombria, a ocultar no silêncio as feridas da alma, recolhida no esforço de encontrar consolo para tanta frustração, faz de Melana uma espécie de reflexo da senhora, como as velhas Amas da tragédia. Denuncia-o Éritra, em choque com a mãe que procura refrear os seus ardores (p. 6): "És tal qual ela! Só escuridão. Merecem-se uma à outra». Esta escuridão produz-se, dentro do motivo que o texto privilegia da força da palavra, pela ausência de expressão verbal, da parte desta mulher que teme a ameaça de novas

\footnotetext{
${ }^{7}$ Este é um motivo caro a Hélia Correia, que se repete nas suas telas do feminino: a humilhação que torna realmente servil a existência, pessoal e social, de uma mulher que teve a desdita de nascer escrava ou deserdada da fortuna; cf. Perdição, p. 34, onde a Ama de Antígona reconhece, como inevitável, esta circunstância: «E todas as criadas jovens, uma a uma, passarão certa noite pelo corpo do senhor. Sem que nisso achem glória ou alegria. É serviço de escrava, como um outro qualquer»; cf. também Rancor, pp. 101-102.
} 
feridas e procura no silêncio uma sombra protectora; só um estímulo poderoso a fará sair dessa atitude fosca, como regista, impiedosa, a filha (p. 15): «Ó mãe! Esqueceste por acaso essa prudência de que tanto te fartas de falar?»

Percebemos já que o que separa Melana de Éritra - para além da geração, um contraste permanente de carácter e de atitude, que se exprime na oposição de tons que cada um dos seus nomes coloca como pano de fundo do seu retrato - é promissor de uma caracterização impressionista. A mesma rubrica de cena que dera de Melana o perfil mais óbvio preparando traços mais precisos, o de uma morena envelhecida e apática, sublinha o contraste com «a jovem que entra, de cabelo ruivo, Éritra, com um alguidar cheio de farinha (...); vem sacudindo-se da chuva e despeja a farinha sobre a mesa» (p. 4). Activa, provinda do exterior, fresca e ágil, a jovem que vem da penumbra de um dia chuvoso para a sombra de um compartimento pouco iluminado é, nas trevas em que se move, um raio de luz e de vida. Isso mesmo reconhece Jasão, quando pergunta ( $\mathrm{p}$. 7): «E Éritra, onde está? Os seus cabelos são o único sol que aqui há dentro» ${ }^{8}$. Constitui a cabeleira ruiva o símbolo fundamental de tudo o que compõe esta figura9. Fazendo da palavra o traço prioritário de uma personalidade, Éritra, extrovertida e esfuseante, pode afirmar como princípio (p. 5): «É das ruivas! As ruivas falam muitom. E acrescentar, com o caso concreto de Glauce, também ela

\footnotetext{
$\overline{8}$ Este mesmo motivo regressa na nota de cena (p. 14) que encerra esta Parte I: «Continua a chover, mas da taça onde as ervas do chá estão mergulhadas em água quente sai uma claridade. A cabeleira de Éritra também brilha».

${ }^{9}$ Esta ideia de concentrar numa cabeleira o ponto de irradiação de uma beleza fatal tem em Helena de Tróia, desde logo, o seu modelo incontornável. Já Homero se refere a "Helena de bela cabeleira" (Ilíada 3. 329) e, com o epíteto eúkomos, a deusas e mortais (cf., e. g., Ilíada 1. 36, 2. 689, Odisseia 12. 389). Eurípides, fiel ao velho motivo épico, mantém a cabeleira como insígnia de uma Helena coquette que, depois de regressada a Esparta, no final da guerra, quando confrontada com a desgraça e a morte que se prolongam dentro das casas gregas no regresso dos heróis, mantém ainda a preocupação de cortar ao de leve alguns anéis de cabelo, como oferenda para a irmã falecida, Clitemnestra, sem lesar a sua bela cabeleira (Orestes 128-129). Hélia utiliza a mesma tradição em Rancor (pp. 43-46), onde os cabelos loiros de Helena representam a protagonista de um mito que ainda alimenta a fantasia dos mais novos, mas que simplesmente se perdeu com a decadência das velhas lendas; Helena usa, na nova imagem de Esparta, uma cabeleira egípcia a ocultar uma simples cabeça rapada.
} 
uma ruiva, na memória (p. 6): "Nunca se cala: faz as perguntas, e responde, e ri-se».

Mas o fulgor dos cabelos tem, em Éritra, um sentido mais profundo que se esconde por trás do seu brilho ofuscante. Ele é a marca da sua identidade, a denúncia de uma filiação que pode funcionar como objecto de reconhecimento ${ }^{10}$. Aquele segredo que Melana, refugiada na sua conhecida prudência, desde sempre ocultara sobre a paternidade da filha aparece exposto, num grito ensurdecedor, pela cabeleira de Éritra. Abar é testemunha dessa revelação (p. 14): «Diz-lhe a verdade. O seu cabelo há muito que o disse a toda a gente!». Logo Jasão é capaz de somar, a esta denúncia geral, uma precisão, acrescentando à identidade um parentesco (p. 16): "Tão bela como Glauce. E tão parecida como sua irmã». Sobre Jasão, foram os cabelos fulvos de Éritra a exercer um primeiro fascínio, sensual, quase inconsciente, mas por isso mesmo genuíno. Como por instinto, a mão do Argonauta estende-se para uma jovem que «evolui alegremente em torno dele» e, mesmo sem de tal parecer aperceber-se, «acaba por pôr-lha no cabelo, distraidamente». Atracção essa recíproca, como mais adiante (p. 35) o comandante da nau Argos recordará ainda: "Pensarás tu que não te olhava dia após dia? Que eu não via o modo como a cor do cabelo de repente te descia para o rosto, se eu passava?» Assim Hélia desdobra e amplia, para o âmago da sua privacidade, a ameaça contra os afectos e a segurança de Medeia. Porque antes de pôr olhos de desejo, e de interesse também, na distante Glauce, Jasão rendera-se à sedução de uma Éritra, próxima e oferecida; assim o confessa sem rebuços diante da escrava ao seu serviço (p. 22): "A culpa é tua. Foi a cor do teu cabelo o que atiçou o meu desejo pela tua irmã».

\footnotetext{
10 Este é também um elemento conhecido da tradição clássica, a que Aristóteles dedicou vários capítulos da Poética (1452 30 - 1452b 8). Particularmente relacionado com os cabelos como o móbil do reencontro entre irmãos há muito afastados é o famoso reconhecimento de Orestes, em Ésquilo, Coéforas 168-200, 229-230, onde Electra valoriza também a cor dos cabelos como o factor de semelhança, que justifica a afinidade natural entre si e o próprio irmão. Eurípides recorda, em tom de crítica, este célebre passo esquiliano, na sua Electra 513-531, e volta a colocar, diante de Electra, uma madeixa loira para a convidar a reconhecer, através dela, a presença de um saudoso Orestes.
} 
Foi inspirado por esse fascínio que se dispôs a seguir a proposta de Creonte e a trocar a bastarda pela filha legítima e próxima do trono (p. 16); sem perder os encantos de uns cabelos que ambas as irmãs partilhavam, ganhava estatuto social e influência política, numa conveniente harmonia entre desejo e ambição. No texto português, a ameaça contra Medeia sobrevive à destruição de Glauce, a noiva prometida; para além da sua morte, Éritra resiste como objecto de uma outra proposta de casamento (p. 35): "Quanto a nós, Éritra, és agora a única descendente do rei. Ninguém duvida de que o seu sangue corre em ti, a ruiva cabeleira, esses olhos o confirmam. Passado o luto, ele te perfilhará. E reinaremos juntos em Corinto». A personalidade de Jasão reforça-se com esta capacidade de se apaixonar, para além de uma simples ligação de conveniência. Como também o cerco se aperta em torno de Medeia, na ameaça que se oculta dentro das paredes da sua casa. "É a cor do sangue», como reconhece Abar (p. 22), que circula diante da mulher repudiada, como uma inspiração.

Ao lado das servas, impõe-se a personagem da senhora, uma estrangeira da Cólquida e figura distante dentro do convívio doméstico. De acordo com um critério de hierarquização, definido pela relação de cada uma das personagens com o uso da palavra, Medeia goza de um ascendente amplamente reconhecido, que a coloca num patamar superior no plano dos mortais, a tocar a prerrogativa excepcional de quem possui dotes de magia. Temem-na os que a cercam, seguros de que a princesa da Cólquida não necessita de ouvir qualquer palavra para entender os pensamentos em sua volta; a reserva ou animosidade dos que a servem é-lhe perceptível, mesmo na ausência de palavras, porque, como Éritra compreende (p. 4; cf. p. 9), «ela consegue ouvir-nos a pensar». Perante a própria ambiguidade dos que lhe são mais íntimos, no limite o homem que ama e o pai dos seus filhos, Medeia antecipa-se às palavras e penetra os pensamentos profundos que lhes estão na origem (p. 18): «Finge nada saber e no entanto já tudo adivinhou. É bruxa».

Mas se um vestígio dos seus famosos «encantamentos" lhe reforça a capacidade de ouvir o silêncio, é com base na língua por que se exprime que a 
nova Medeia constrói a sua personalidade de mulher e de bárbara. Este é um lado particularmente relevante na Medeia euripidiana, aquele que valoriza o sofrimento solitário da exilada, distante dos seus, esforçada na adaptação a um nomos alheio e desconhecido, mas vítima de desafecto e de repulsa num mundo que lhe recusa um verdadeiro acolhimento. Idêntica solidão é valorizada por Hélia Correia, expressa no «distanciamento linguístico» que afecta a estrangeira. Desde logo o corte da esposa de Jasão com tudo aquilo a que pertencia é por ela mesma expresso numa confissão significativa; diante da iminência do corte da última das amarras que faz dela um ser social - a aliança com o Argonauta - Medeia protesta (p. 21): «Aquilo por que eu deixei família, e pátria, e língua, e tudo o mais, a vida», recordando essa paixão fatal que a privou das que são condições essenciais à normalidade saudável da existência. Sobre o passado correu uma cortina de silêncio, reservando só para si a imagem de uma Cólquida - «Medeia nunca nos falou da Cólquida», p. 25 - que entendeu ocultar do mundo estranho de Corinto - «a minha história é só a minha história", p. 25.

Todavia, por uma necessidade muito humana, Medeia tentou restabelecer na Grécia os pilares necessários a uma construção de estabilidade e de rotina. Empenhou-se em organizar uma nova família, núcleo essencial de uma protecção baseada nos afectos; procurou acomodar-se numa outra pátria, onde a sua presença e inclusão fosse tolerada. Mas, como arma suprema - e aqui reside, em Desmesura, um elemento estranho à tradição do processo, conforme todavia com a linha dominante na criação de Hélia que seguimos -, esforçou-se por transplantar para o mundo novo a sua língua, para ela um traço estruturador da sua verdadeira identidade. Tentou criar, a esse nível, uma conivência com Abar, a escrava núbia, ela também uma estrangeira em terra grega; quis estabelecer com esta aliada natural uma cumplicidade linguística, ensinando-lhe o colco e assim construindo, entre ambas e o mundo hostil em sua volta, uma barreira de protecção. Sem sucesso, no entanto, porque em Abar não encontrou o eco da sua personalidade fogosa e determinada. É esta a imagem que 
prevalece no quadro da aparição de Medeia, no que é a valorização implícita da faceta que se quer mais relevante no retrato, a de uma Medeia expatriada. Em desespero de levar a bom termo a sua tentativa, a senhora tem, perante a escrava núbia, aprendiz renitente das suas lições de língua, uma reacção de fúria, que é ao mesmo tempo um traço caracterizador da sua natureza desmesurada e o sinal evidente de desespero e desadaptação que, como nunca, lhe pesa sobre os ombros. Em nota de cena, Hélia sumaria assim o quadro da chegada das duas mulheres (p. 9): "Medeia atira Abar sobre uma esteira com uma exclamação enfurecida. Fala-lhe em língua estranha; Abar responde primeiro na mesma língua, depois começa a falar em grego, obrigando Medeia a acompanhá-la». Frágil e incapaz de corresponder à determinação da sua senhora - uma espécie de Ismena junto de Antígona, quando se trata, para as filhas de Édipo, de defender as prerrogativas da família -, também Abar desempenha, em contraste com Medeia, a função de uma espécie de espelho reflector de diferentes sensibilidades perante uma mesma crise. A pobre núbia, irmã de Medeia pela condição de estrangeira que ambas partilham, não hesita em confessar a debilidade que lhe caracteriza o espírito e a atitude - «Senhora, não me obrigues a falar na tua língua. Eu não consigo. Esqueço. Tenho a cabeça fraca», p. 10 - e a impossibilidade de corresponder ao impulso que comanda cada gesto da sua companheira, de rebelião e de exílio - «És a única com quem posso falar a língua dos meus pais e da feiticeira, minha tia. É o meu único consolo aqui. Vamos, fala-me em colco. Faz um esforço». No entanto, não lhe falta compreensão pela dor íntima que aflige Medeia, mas que exprime de uma outra maneira. Também ela empenhada na busca de uma identidade perdida, não é da força das palavras, talvez de contestação ou de um protesto activo, que se arma; o maior conformismo de que é dotada aconselha-lhe o silêncio e a procura de um pouco do sol dos antepassados, a cujos raios se acolha como a um refúgio discreto, mas consolador (p. 10), que convida à passividade ou até, quem sabe, ao asilo eterno que a morte generosamente concede. 
Entre ambas está instalado um conflito de culturas, que torna a incompatibilidade de origens mais plural ainda e mais precisa. Dois factores igualmente relevantes caracterizam diferenças e distâncias entre criaturas provenientes de horizontes afastados: a língua e o clima. Desde o primeiro momento que a natureza helénica reagiu à presença de Medeia; uma incompatibilidade profunda entre uma Grécia «Soalheira» e mediterrânica e a mulher do norte teve o dom de tornar suspeitas as conversas mais banais e descomprometidas. O aparentemente inócuo comentário sobre o tempo que faz - «ah, como chove!...», p. 5 - pôde servir de código para exprimir a tradicional incompreensão e suspeita a separar Gregos e Bárbaros (p. 5): «Toda a gente em Corinto passa a vida a estranhar estas chuvas tão intensas. Eu própria me recordo como era tão cheia de sol esta cidade. E quente! Os Invernos passavam num instante. Desde que ela chegou, vivemos nisto..." ${ }^{11}$ Mas incompatibilidade equivalente separa também as duas estrangeiras, frio e calor marcando uma distância de antípodas entre a colca e a núbia. Porque se é manifesto, quanto a Abar, que «ela morre de chuva e escuridão", planta de solo quente tristemente transplantada para clima hostil, também Medeia sofre de igual ameaça, mesmo se inversa (p. 12): «Mas sob o vosso sol morria eu».

Se relevante é, todavia, para Medeia o alento de ouvir falar a sua língua, menos sensível neste ponto, Abar aceitou, com os diversos códigos que foi assimilando, a condição apátrida de uma escrava estrangeira; à sua língua materna, acrescentou o grego e mesmo o colco, flutuando, na palavra como na sorte, ao sabor de um destino sem rumo; recuperar a sua língua é, na instabilidade do exílio e servidão, um regresso à meninice que, para Abar, equivale ao fechar de um anel que se chama existência (p. 20). Perdeu assim o domínio de uma arma que Medeia manuseia com mestria e efeitos visíveis. Ao lado de uma Abar que se estiola por falta de calor, uma condição que não domina e a expõe à

11 Cf. pp. $11,17$. 
hostilidade e extinção em terra estranha, a princesa colca insiste em pronunciar estranhas palavras, que são o protesto da sua origem, e que aos ouvidos do Grego soam como uma reacção desconfortável, mas eficaz na revolta que exprimem (p. 17): «Para que insistes nisso? ... Em falar essa língua com a núbia!

Estás cheia de atitudes antipáticas!»

Se a divergência linguística resulta, entre Gregos e Bárbaros, em hostilidade, a comunidade que o conhecimento do colco estabelece entre as duas exiladas tem o condão de, mais do que aliá-las na reacção ao exterior, de uni-las entre si, na revelação do lado oculto de uma natureza que só pelas palavras exactas se pode desvendar. O que escondera de todos os Gregos que a cercam, a intimidade da sua história colca, Medeia foi confidenciando, quase que involuntariamente, à sua única verdadeira interlocutora, Abar, a discípula a quem a sua língua se tornou penetrável. Por isso a núbia desfia todos os crimes do passado da senhora (p. 11) e pode reclamar a competência privilegiada de uma confidente (p. 27: «Ah Medeia, eu conheço-te tão bem ... Não foi em vão que me ensinaste a língua em que te iniciaste nos feitiços. As palavras não são senão o espírito das coisas que nomeiam. Sim, não vi somente o teu país. Eu vi-te a alma tão negra como tu. De certo modo, há entre nós um esboço de irmandade».

Para além desta relação mesmo se difícil, privilegiada com Abar, todas as outras teias humanas que vai tecendo em Corinto são marcadas pela desadaptação e conflito. Em círculo mais estreito, entre mulheres, sem sair dos limites do dia-a-dia doméstico imposto à condição feminina, Medeia tenta demarcar com nitidez o seu estatuto de senhora, a mão da autoridade sobre as escravas que a servem. Também este lado da personalidade da sua heroína o constrói Hélia com base no poder social da palavra. Porque afinal hierarquizar uma sociedade é um processo que se denuncia basicamente como um jogo de palavras, cuja correspondência com a realidade é precária. Num núcleo doméstico onde a identidade de cada um se revela como dúbia ou aparente, são as palavras que, como um carvão, legendam em traço nítido a verdade sob cada figura. É essa a questão que se instala no primeiro diálogo da peça entre as duas escravas, 
mãe e filha, Melana e Éritra. No afã doméstico que as identifica como servas, instala-se a reflexão sobre o que seja o comportamento correspondente à sua condição. Cada reacção, mesmo a mais legitimamente humana - ou não são os sonhos, pelo menos, direito natural e rasgo de liberdade de cada homem? - se reflecte, como uma privação, sobre o estatuto do servo. Educar Éritra é para a mãe um exercício de combate à espontaneidade da natureza, dentro de uma metodologia ponderada do uso do silêncio e da palavra. Reprimir é silenciar, até as observações mais espontâneas, pelo que em todas elas possa existir de perigoso ou ousado. Domesticar é repetir palavras, que tenham o condão de substituir, ao instinto natural, o poder dominador do nomos (p. 4): «Éritra - Estás sempre a recordar-me. - Melana - Que tu és uma escrava? Realmente parece que te esqueces muita vez. Olha, desta barriga é que nasceste. Uma filha de escrava escrava é». Para depois, sobre a massa natural, imprimir traços de uma identidade que integra cada criatura nos sucessivos núcleos sociais, família e comunidade. Também neste momento, a construção por palavras de uma certidão de nascimento concorre com vantagem sobre o verdadeiro trabalho da natureza. É a própria dúvida que parece exigir o constante empenho de uma retórica convincente ${ }^{12}$ (p. 5): «Éritra - E o meu pai? - Melana - Já to disse e repeti. - Éritra - Um escravo trácio que morreu nas minas. - Melana - Exactamente. Um escravo trácio. E então? - Éritra - E como era o seu nome? - Melana E tu insistes! - Éritra - É que já me contaste tanta história ... E em nenhuma

\footnotetext{
12 A dicotomia nomos / physis relaciona-se, entre os Sofistas, com Protágoras e coloca a famosa questão da individualidade como um oposto àquilo que são as práticas ou o conhecimento aceite por toda a comunidade. Para além do que é empírico e que não exige, portanto, a deliberação ou a opinião da cidade, há os valores, que se situam no campo da justiça, da moral, da convenção social sobre os quais é também o ser humano a decidir, não individualmente mas em grupo, e a exprimir-se por meio da linguagem. A palavra terá de ser então escrupulosamente ajustada ao conceito que representa. É à educação que cabe transmitir esse conhecimento, que é capaz de alterar as disposições instintivas de cada indivíduo e de o transformar num verdadeiro cidadão. E é pelo discurso que o processo se concretiza, ou seja, que cada um se educa ou forma como membro de legítimo direito de uma cultura. Cf. E. Dupréel, Les Sophistes, Neuchâtel, 1948, pp. 22-30; G. B. Kerferd, The Sophistic movement, Cambridge, 1981, cap. X; W. K. Guthrie, The Sophists, Cambridge 1971, cap. IV.
} 
delas acredito». A própria natureza se encarregará de reclamar os seus direitos. Naquela cabeleira fulva que grita de exuberância no nome de Éritra, a physis como que faz ouvir o seu protesto, num agôn com nomos, seu permanente adversário. Mas, sob a pele, num nível oculto mas igualmente sensível, a perspicácia de que é dotado o espírito de Medeia adivinha um outro grito natural, que responde à dúvida de quem procura uma desejável conformidade entre verdade e aparência (p. 12): «Éritra - E poderás dizer-me aquilo que minha mãe me tem calado? Meu pai quem foi? - Medeia - Que queres que te responda? O que o teu sangue já adivinhou?»

Definidos os encadeamentos genéticos, vem depois a atitude, que cabe à paideia ir construindo por um longo processo de correcção e de repressão. Moldar o recorte de um escravo, filho de escravos, é tomar uma opção radical numa outra célebre dicotomia, que parece condicionar o comportamento em sociedade: palavra/acção. Falar é, para os escravos, uma arma de protesto, aquela ferramenta que lhes permite quebrar as grilhetas, pensar e exprimir-se como seres autónomos e livres, ultrapassar os limites coercivos da humilhação a que a sociedade os submete. Porque incompatível com a subserviência que deles se espera, a palavra é um luxo que lhes está proibido e o silêncio uma qualidade que têm de aprender, num difícil processo de conformação a uma identidade que lhes é imposta. Melana assimilou, com o tempo, essa imposição, resguardando, num silêncio discreto e prudente, a história de quem se tornou escravo ${ }^{13}$ (p. 9); com o sangue que, por herança, transmitiu à filha, quis transmitir-lhe também esse segredo de "comportar-se» como uma serva. A lição é simples, mesmo se dolorosa e contra natura (p. 9): «Eu ensinei-te a temer as palavras. São um luxo a que os Gregos se entregam por prazer como o vinho e os jogos. Para nós, é como alimentarmos a serpente dentro da própria boca. Quem espreitar para dentro de uma casa poderá distinguir os escravos pelo silêncio».

\footnotetext{
$\overline{13}$ «Éritra - Quem te escravizou, mãe? - Melana - É história antiga. - Éritra - Que nunca me contaste».
} 
Se inibidos no uso da palavra - o que desde logo os coloca, na sociedade que inventou a grandeza de uma convivência democrática consagrada por uma expressão livre, no plano humilhante de propriedade ou objecto -, dos escravos é sobretudo esperada acção que, no seu caso, é estigma também de humilhação e servilismo. Executar, em silêncio, a rotina da casa é emblema natural de quem é escravo. Sonhar, falar são luxos proibidos, quando o dever manda amassar o pão (pp. 4, 13). Só mesmo a natureza terá o direito de lhes restituir aquilo que a sociedade humana bloqueou (p. 13): "A morte, mais piedosa que tu, estendendo a mão, compra-me sem moedas. Como todos, mudo por fim de dona».

Ser livre e objecto de uma timê reconhecida contém em si a prerrogativa de falar, ou antes, de ordenar e ver-se obedecido sem hesitação. Assim convive uma sociedade onde o poder fala pela boca dos que habitam os palácios, mesmo se a natureza de tal parece inibi-los. Glauce é jovem, mulher, imatura e despojada de autoridade. Mas é princesa, e por esse estatuto que o nomos lhe confere, ganha voz activa e impõe-se sem recalcitrações; os que manda chamar comparecem, porque afinal (p. 6) «É a princesa. Manda mais do que tu. Mais que Jasão», reconhece Éritra perante o desagrado da mãe, afinal uma simples escrava; mesmo se desobedecida, Melana não deixa de reflectir, rendida a critério semelhante (p. 6): "Menos que o rei. Se o rei te proibir ..." No fundo desta escala social vêm os escravos que, se obrigados a quebrar o silêncio que os distingue, exprimem os limites que a própria condição lhes impõe numa submissão que se espera das respostas que deles se solicitam (p. 6): «Isso é resposta que uma escrava dê?»

Mais uma vez ambígua é a situação de Medeia. Excluída pela sua natureza de bárbara da hierarquização proposta por uma sociedade onde se mantém uma estranha, a princesa da Cólquida é, mesmo assim, a mulher do herói, em quem vagamente se reconhece "a senhora da casa». Mas a fragilidade da concessão, de alguém que continua a ver no estrangeiro o intruso, denuncia-se, desde logo, no que é o território feminino, onde a mulher grega impõe a sua autoridade. 
Medeia vê-se compelida a reclamar a certidão de um estatuto que a palavra "senhora» restabelece. O próprio nome - o de Medeia - lhe parece impróprio e quase insultuoso, banalizando, na boca de uma escrava, os seus pergaminhos de princesa (p. 12): «Senhora! Assim se trata uma princesa. Esqueces? Julgas tu que, por me encontrar longe do meu reino, fiquei desprotegida?»

Este protesto, em nome da estabilidade e segurança, cai em ruínas, quando o desamor de Jasão retira à bárbara todas as prerrogativas. Vilipendiada pelas criadas (p. 13), vê fugir-lhe aquele nome de «senhora» a que se agarrava como uma náufraga (p. 18). Se na palavra "senhora», porém, a estrangeira quer recuperar o vislumbre de uma autoridade que perdeu ao exilar-se, ela não basta para trazer um conforto mais profundo à sua solidão, o do afecto. A própria reconhece que à Senhora é devido, como homenagem, o temor, mas excluído, como dádiva com ele incompatível, a amizade (p. 12). Esta é a verdade que Medeia vem penosamente a constatar quando, experimentada por tanto sofrimento, procura naquelas que a tratavam por «senhora» a compreensão, que a natureza consente entre mulheres, mas que o estatuto social torna impossível (p. 24): «Medeia - Somos todas mulheres. Quem me humilhar a vós humilha! Não sofremos nós com as mesmas bebedeiras dos senhores, com a posse brutal e com os partos? - Melana - Nunca tiveste essa conversa. Foste sempre tão arrogante, tão temível. Perder Jasão tornou-te humilde, foi?»

Mas, no campo dos direitos e afectos, o principal agôn que Medeia tem de travar, consagrado pela velha tradição euripidiana, é com Jasão, o amante e pai dos seus filhos, mas traidor. Tal como a Ama, no modelo grego, anunciava, na tensão que pressentia no ar confirmada pelo rosto furioso de Medeia, a proximidade de uma crise grave, também as novas servas, suas substitutas no oikos da heroína portuguesa, captam o efeito das tensões que sacodem um lar em ruptura (p. 6): «Éritra - Nesta casa o melhor é fingir que somos mudos. - Melana - Ora aí tens! De um mudo não resulta desastre algum».

O recontro entre Jasão e Medeia reserva-o Hélia para a Parte II do seu texto, depois de desenhado com cuidado o espaço de contestação contra a senhora 
no plano da autoridade doméstica. A entrada do Argonauta desencadeia um conjunto de sinais negativos (p. 14): «tem um ar desconfortável, preocupado», pergunta sem preâmbulo por Medeia como se ela fosse a ideia obsessiva que o domina, mal repara no jogo de sedução da jovem Éritra, na quebra do que adivinhamos ser seu costume. É assim que o amante de outrora se aproxima da mulher que um dia seduziu e que, apesar de um longo caminho de afastamento, se vestiu e penteou com o cuidado que merece um encontro de amor. Antes que a imagem da colca se lhe ofereça, empenhada num já cansado exercício de atracção, o recém-chegado reage à visão de Abar que lhe traz à memória - em sons indesejáveis - o pesadelo da sua vida (p. 14): "Novamente terei de ouvir falar aquela língua que é um ultraje à Grécia?» Ensimesmado com tormentos íntimos, Jasão não recupera do que é a sua tradicional hesitação ou cobardia. Se a deixou patente na execução da campanha suprema da sua carreira de herói - não fora a ajuda de Medeia e não teria sido capaz de dominar o dragão de guarda ao almejado velo de ouro! -, nunca a escondeu diante da vontade feroz de uma companheira, que lhe tornou a existência numa aventura permanente. Tão profundo é o seu temor perante a fúria de Medeia, que nem para o reconhecer lhe resta ânimo. Afligem-no, por isso, a par de pruridos de herói, reivindicações de marido, humilhado à ideia do domínio feminino de que não logra soltar-se. Exprimir por palavras esse seu sentimento, "Confessar» o medo que o atormenta é também façanha acima do alcance deste homem. Por isso a revelação desassombrada que uma escrava, em nome de prerrogativas que o convívio consente, ousa fazer da alma do senhor soa como um «insulto» (p. 15), quando não passa do simples registo oral de uma realidade irrefutável ${ }^{14}$.

\footnotetext{
14 Já na tradição grega, Jasão é modelo de um herói decadente e envilecido. De conquistador e comandante de uma empresa arriscada, foi-se tornando num homem vulgar, egoísta e centrado no seu bem-estar, material e social, tão cobarde e dependente na conquista de um tesouro, como no que apenas diz respeito à gestão do quotidiano.
} 
Adivinhando o agôn tremendo que se avizinha, Jasão escolhe cenário e ocasião mais convenientes $^{15}$ a uma fragilidade que melhor que ninguém em si reconhece; contrariando a intimidade necessária a um confronto entre marido e mulher, nas crises que afectam o casamento, Jasão prefere a cozinha, o coração exposto da casa, e o testemunho das criadas, como um chefe fraco cujo sucesso depende do apoio das companheiras, em quem adivinha aliadas na cólera contra Medeia (pp. 16-17).

A mesma impotência, que o cenário do encontro já espelhava, se patenteia nas acusações que Jasão não ousa chamar suas, mas que desfecha por trás da voz anónima de um «todos em Corinto», para quem comodamente transfere uma repulsa que se vai tornando ódio (pp. 17-18): «Em Corinto todos se afastaram de mim por tua causa»; "todos te culpam pela chuva que não cessa de cair». Medeia reconhece, neste discurso inusitado, o herói fraco de outrora que ajudou na Cólquida. Do coro de recriminações de que a voz das criadas se faz eco, Jasão não sabe colher força, mas a debilidade patente de um homem a quem a tagarelice feminina submerge (p. 19); vítima de um mau sentido de kairós por que a sua cobardia é responsável, expõe-se agora, num terreno feminino que não domina, à tremenda prova de «encontrar as palavras certas» para exprimir, por trás da máscara de «todos em Corinto» os seus sentimentos e razões. Medeia estimula-o a falar, antecipa perguntas para facultar revelações. Mas falha ela também, a maga que tem fama de ouvir falar os pensamentos; colhida pela notícia das bodas com Glauce, emudece.

Este silêncio, que é também recuo sobre si própria e nega de uma última condescendência, revela em Medeia o recrudescer da ira e da violência. Adivinha-o, por intuição, o traidor, que passa a multiplicar razões (pp. 19-20),

\footnotetext{
15 A noção de kairós, o sentido da oportunidade que traz êxito ao discurso, observados o tempo e teor dos argumentos, é associada por Diógenes Laércio (9. 52) com Protágoras; Górgias voltou mais tarde ao mesmo conceito. Cf. A. Plebe, op. cit., pp. 14 sq., 18; M. Untersteiner, Sofisti. Testimonianze e Frammenti, I, Firenze, reimpr. 1967, pp. 18-19.
} 
numa tentativa de se refugiar nos argumentos; mas vai mais longe Jasão: numa cedência espavorida, pede até a Abar que fale em colco, que dê à dureza da sua confissão o mel suavizante da língua materna. Para ouvir de Medeia uma acusação directa e sem rebuços (p. 20): "Cobarde. Não te escondas atrás dela. Já te não servem as palavras gregas, tens medo de as sujar com a pestilência de um coração traidor?» Novos argumentos de Jasão inspiram-se nos do seu modelo; da explicação passa à mentira, afirmando, como única preocupação, os interesses dos filhos (p. 20), arredando da aliança com Glauce qualquer motivo para além de um simples acordo (p. 21). Para se confrontar, tal como o Jasão de Eurípides, com a agressividade de uma adversária impiedosa (pp. 2122): «Não fales dos meus filhos! Não os uses como argumento para o teu desejo de te deitares com Glauce! Não transformes o instinto animal numa estratégia!». De novo Hélia, pela voz irada mas lúcida da sua heroína, afirma aquela que é, mais do nunca, a tensão que preside ao conflito, physis reclamando os seus direitos sob o verniz elaborado de nomos.

Trocadas palavras de denúncia que trazem à luz a verdade por trás das aparências, a ruptura torna-se decisiva; rasgou-se o último fio que prendia duas existências num caminho sem retrocesso. Antes apátrida pela fronteira que actos violentos ergueram entre Medeia e os seus, é agora Jasão a construir uma outra parede que a isola do mundo da humanidade e dos afectos (p. 22): «Nem vosso Zeus podia fazer voltar o tempo àquele instante em que ainda não tinhas dito nada. O mundo acabou. Começou outro» ${ }^{16}$. Para trás ficaram etapas que construíram um percurso de vida, opostas, no desfecho que tiveram selado pelo amargor das palavras, àquele tempo em que, entre Medeia e Jasão, existia uma

\footnotetext{
16 Esta ideia de que as palavras - quer as que constroem uma lenda, quer as que antagonizam criaturas humanas - possam ser um elemento propulsor na existência, colectiva ou individual, é um tópico repetido nos textos de Hélia Correia; cf. Rancor, p. 56: «Helena - Sempre a mesma conversa! Haja paciência! Já era altura de mudar de assunto. Etra - Como se fosse um passo de magia. Como se cada um abrisse os olhos e regressasse ao tempo antes de Helena». Afirmação semelhante é feita pela Ama de Medeia em Eurípides (1-13) que desejaria que o passado se desfizesse, para que a vida regressasse ao seu ponto de partida.
} 
sintonia de almas, que dispensava a necessidade de uma formulação. Nessa altura, o Argonauta nada teve de pedir ou de explicar para garantir a adesão da princesa, por condição social inimiga. Então, nas profundezas destes dois seres, a natureza cantava hinos de amor e de empatia (p. 33). O sentimento profundo e verdadeiro dispensou palavras, talvez mesmo elas o deturpassem e confundissem. Só a hipocrisia e ocultos interesses as exigem agora, elaboradas, falsas, persuasivas.

Jogada entre sentimentos, intenções, objectivos inconfessáveis, ditados por impulsos contraditórios na alma humana, a história de Jasão e Medeia avalia-se pela precisão difícil das palavras. Orthoépeia, "O rigor da expressão", é um conceito a que Hélia regressa. Encontrar, para a fluidez das reacções emotivas, o nome exacto, dispõe das almas e condiciona a narrativa. Será "amor» a palavra certa para rotular a experiência vivida pela mulher colca e pelo chefe da nau Argos? ${ }^{17}$

Importa primeiro definir «amor». Experiente, Melana sentencia (p. 8): «Não se chama de amor um sentimento que existe só durante a escuridão", e assim alude a uma relação gratuita, esporádica, inconsequente como a que une o senhor aos encantos de uma escrava. Entre esposos o caso é diverso; mas aí, tudo o que seja apelo à sedução, estímulo ao impulso amoroso parece impróprio, desgastado por uma espécie de convencionalismo social (p. 14): «Melana - Ela está à tua espera. Vestiu-se, penteou-se para ti. Decerto se estendeu no vosso leito. - Jasão - Pareces uma velha alcoviteira. Isso não são maneiras de falar para esposos com filhos». Mas o casal que nos é dado ouvir vive a hora em que o tédio é sacudido pela ameaça de ruptura. Medeia reage à ideia de uma rival nas atenções de Jasão; e nos seus protestos vibra «o orgulho, não o amor» (p. 22). A forma como avalia a traição é nivelada por uma natural desmesura

\footnotetext{
17 Este é um dos motivos mais flutuantes em toda a tradição do mito de Medeia, definir que tipo de relação aproximou a princesa de Jasão. Cf., e. g., Medeas. Versiones de un mito desde Grecia hasta boy, I-II, ed. A. López e A. Pociña, Granada, 2002.
} 
de carácter; por isso falta, para aquela revolta tremenda de que só ela é capaz, a palavra certa (p. 25): «Melana - E deveremos chamar amor a coisa tão medonha? - Medeia - Decerto não, eu bem procurei essa palavra nova. Não existe. Se houvesse uma palavra, eu poderia talvez achar conforto, convertê-la num sentimento que me consolasse». Porque a sede de violência que a afecta se não satisfaz com a destruição da rival e com o reflexo inevitável que terá em Jasão, Medeia vai mais longe, usa os filhos como instrumento de vingança, valendo-se da inocência das crianças como escudo contra qualquer suspeita. Não parece que seja só pragmatismo o que a leva a deitar mão desta estratégia. Ao envolver os filhos na tragédia, ela aposta na destruição total do lar que construiu e no aniquilamento de si mesma. Este excesso que transparece dos seus actos deixa atónitos os que os presenciam. Melana e Abar, mulheres da sua intimidade, procuram ainda compreender, ou seja, nomear tamanho turbilhão de alma (p. 28): «Abar - A pobre! Causaria compaixão se se chamasse angústia aquilo que sente. Mas em nenhuma língua eu sei dar nome à coisa sem medida que a possui. - Melana - Tu não conheces a palavra, Abar? Nunca a pronunciaste? É o ciúme. - Abar - Isto é mais que ciúme. É desvario».

Este amor, que o abandono fez ascender a ciúme, para finalmente se elevar a desvario, conhece o seu momento de justificação perante o Argonauta furioso, desfalcado de uma noiva que para ele representava a conquista de um novo tesouro. Conduzido, uma vez mais, pela mão de uma donzela apaixonada, o herói preparava-se para conquistar uma posição de prestígio e autoridade entre o povo a que pertencia. É a raiva o que torna loquaz e desmedido de palavras o Jasão, que conhecemos cobarde e temeroso. Loquaz e desmedido, que não oportuno ou subtil nas confissões que faz, numa revelação isenta de subterfúgios ou de mentiras. Jasão não grita o seu arrependimento, por ter cedido à sedução daquilo que Medeia um dia significou para os seus interesses do momento, a conquista de um tesouro e de uma coroa de herói que o redimisse da humana mediocridade. Na sua ira lança, como um insulto, a palavra "gratidão", onde era "amor» o que se esperava ouvir (p. 32). E a uma 
Medeia perplexa perante a evidência do que fora até então uma suspeita, o Argonauta remenda, sem atenção pela orthoépeia, arma de sucesso num agôn, como na vida: "Amor. Talvez. São precisões desnecessárias, essas». É decerto esta confissão, desajeitada mas sincera, que desperta em Medeia o projecto do último dos seus crimes. Porque muitos - é o momento de recordá-lo - foram os que cometeu em nome da ambição do seu amado; até ao limite de "amor» se ter tornado sinónimo de «morte e violência». Não é sem razão que o Argonauta pode reconhecer (p. 32): «Dá-se o nome de amor a muita coisa. Até a uma força que destrói», no preciso momento em que um ruído anuncia a aproximação das crianças. Num derradeiro esforço de salvação, Medeia tenta ainda aliciar Jasão para a fuga, de Corinto, o limite dos seus sonhos, num regresso à Cólquida, que é também o retorno ao que foi o cais de partida para a sua aventura ${ }^{18}$. Porém Jasão tem também o seu projecto de um futuro, uma nova odisseia nos seus sonhos, onde têm lugar os filhos, os cabelos fulvos da jovem Éritra e, por moldura, a luz quente e esplendorosa de Corinto; para ser perfeito, o sonho contempla ainda as seduções do trono e do poder, onde se Jasão não chega pela mão de Glauce, a herdeira legítima, pode talvez chegar pelo amor de uma bastarda, Éritra, que o velho Creonte não deixará de reconhecer. Há coerência no projecto, que renova, com toques ligeiros, o quadro de ventura que almejava. Coerência não falta igualmente a Medeia, mais uma vez repudiada, ao predispor-se ao crime, reacção extrema que sempre foi a sua em momentos de dificuldade. É, como em Eurípides, longo o monólogo com que Medeia avalia o estado de alma que a domina na hora do filicídio. Na suspensão de um golpe

\footnotetext{
18 É oportuno recordar, a este propósito, os comentários que valorizam, na Medeia euripidiana, a capacidade de pronunciar palavras mais próprias da moral heróica antepondo, a interesses materiais, valores do espírito e de afecto. É talvez essa a faceta que Hélia patenteia com esta proposta da sua heroína, que tenta ainda despertar no herói decadente que é Jasão ideais de dignidade e amor. A incompreensão que responde à sua proposta deixa-a isolada, como uma espécie de herói sofocliano, traído, humilhado, mas resistente e inquebrável. Sobre esta perspectiva, cf. K. M. W. Knox, "The Medea of Euripides', Yale Classical Studies 25, 1977, pp. 193-225; E. Bongie, 'Heroic elements in the Medea of Euripides', Transactions and Proceedings of the American Philological Association 107, 1977, pp. 27-56.
} 
que a todos fere - Jasão, o infiel, os filhos e o âmago do seu próprio coração - ela encontra ainda uma palavra que lhe dá o alento derradeiro (p. 37): «Essa palavra que os designa - mortais - não significa que tarde ou cedo hão-de morrer?»

Aqui termina a história de Medeia e começa a de uma cultura que deu forma e som ao seu sentir e ao seu viver. Porque contar o mito dos Argonautas será sempre pôr os olhos numa cultura, que colocou a sedução das palavras entre os supremos prazeres (p. 9). Sobre elas construiu-se uma outra noção de sociedade, dando a cada cidadão, como regalia suprema por todos reconhecida, a liberdade, que é também o direito de falar, sem limites nem temores (p. 9). Ter a prerrogativa de ser grego, e assim ter acesso a um mundo claro e superior, que contrasta com o bárbaro, é, antes de mais, conhecer a língua, mas também aspirar a uma glória que perdura para além da vida, imortalizada pela voz dos poetas (p. 13): «Glória alguma equivale à de reinar numa terra cantada pelos poetas. O que não é narrado, não existe».

É toda essa glória que Medeia desejava para os seus filhos, a de serem gregos de pleno direito, na vida como na memória eterna que domina a própria morte. Até constatar, nas palavras despudoradas, mas por seu mal verdadeiras, de Jasão que também este sonho era ilusório (p. 20). "Os filhos da estrangeira» não são afinal gregos, nem, de direito, herdeiros do trono de seu pai. Por isso se tornam simples objecto de manipulação entre progenitores desavindos: "argumento de desejo" para Jasão, "poção" nas bruxarias vingativas de Medeia. Repartidos entre forças em litígio, assim são desmembrados entre vida e morte. É esta a decisão suprema de Medeia (p. 37): «Meus filhos vão comigo para casa. Levarei deles o que de mim descende, a metade divina. Quanto aos corpos ofereço-os, estendidos, a seu pai».

Este é o remate da história de Medeia, que tal como os sentimentos jogados neste episódio, se afirma estranho, desconhecido, indizível. Atónitos se quedaram os que a ele assistiram ou dele foram parte. Como atónitos se hão-de quedar todos aqueles a quem for servido o eterno enigma desta história. É esse 
o desafio que Hélia faz vibrar no último apelo da sua Medeia (p.38): «Cidadãos gregos, tudo o que vos cabe é somente ir contando a minha história até que um de entre vós a compreenda!» Afinal apenas uma questão de orthoépeia, para traçar o retrato preciso do que é insondável e fluido: os recônditos obscuros da alma humana. 


\section{Série}

\section{Documentos}

Imprensa da Universidade de Coimbra

Coimbra University Press

2006

- $\mathrm{U}$

C • 